\title{
ANALISA BREAK EVEN POINT DAN NET PRESENT VALUE BERDASARKAN INPUT TARIF YANG BERLAKU DI KLINIK KESEHATAN AL-JADID SURABAYA
}

\author{
Kalam Mollah \\ Fakultas Teknologi Mineral dan Kelautan- Institut Teknologi Adhi Tama Surabaya, \\ Email : drs.kalamullah@yahoo.com
}

\begin{abstract}
Yayasan Nur Fadila operating in several regions in Indonesia such as Surabaya, Malang, Kediri and Semarang has been focused on the development of the boarding school with learning science based on the Islamic religion and general knowledge. But for now Hidayatullah develop community health clinics around the boarding school. As one of the new buildings operate in an environment hut, then the clinic needs to do a re-analysis of the rates in effect at this time. The method used to solve the problem is the method of Break Even Point and Net Present Value at the rate of 12\%. In the settlement with the BEP method will put the current rate. From this analysis was obtained on condition BEP tariff of Rp 36 919. By trial and error in the cash flow through Net Present Value approach is to add a class fares on condition Point Break even assuming the increase $x \%$ of the normal rates on BEP conditions in order to obtain the Net Present Value is greater than zero. Thus obtained results which sought class fare on the condition NPV is Rp 92298 , - .
\end{abstract}

Keywords : break even point, net present value, clinic, tariff

\begin{abstract}
ABSTRAK
Yayasan Nur Fadila yang beroperasi di beberapa wilayah di Indonesia seperti di Surabaya, Malang, Kediri dan Semarang selama ini berfokus pada pengembangan pondok pesantren dengan berbasis pada pembelajaran ilmu agama islam dan pengetahuan umum. Namun untuk saat ini Hidayatullah mengembangkan klinik kesehatan bagi masyarakat sekitar pondok pesantren. Sebagai salah satu gedung yang baru beroperasi di lingkungan pondok, maka klinik perlu melakukan analisis ulang tentang tarif yang berlaku pada saat ini. Adapun metode yang dipergunakan untuk menyelesaikan masalah tersebut adalah metode Break Even Point dan Net Present Value dengan suku bunga sebesar 12\%. Dalam penyelesaiannya dengan metode BEP maka akan dimasukkan tarif yang berlaku saat ini. Dari analisa ini diperoleh tarif pada kondisi BEP sebesar Rp 36.919. Dengan cara trial and error pada cash flow melalui pendekatan Net Present Value yaitu dengan menjumlahkan tarif kelas pada kondisi Break even Point dengan asumsi kenaikan $\mathrm{x} \%$ dari tarif normal pada kondisi BEP sehingga diperoleh Net Present Value yang lebih besar dari nol. Sehingga diperoleh hasil tarif kelas yang dicari pada kondisi NPV adalah sebesar Rp 92.298,--
\end{abstract}

Kata kunci : titik impas, net present value, klinik, tarif

\section{PENDAHULUAN}

\section{Latar Belakang}

Klinik kesehatan merupakan bagian yang integral dari keseluruhan sistem pelayanan kesehatan yang dicanangkan oleh pemerintah. Banyaknya jumlah klinik kesehatan tentunya akan menimbulkan persaingan yang ketat serta menimbulkan tantangan yang sangat besar bagi para pengelola maupun pemilik klinik agar kegiatannya tetap lancer [1]. Kegiatan pengelolaan rumah sebuah rumah sakit juga kompleks dengan disiplin - disiplin ilmu antara lain ilmu kedokteran, keperawatan, teknik, ekonomi, hukum maupun humas. Klinik kesehatan yang baik harus mampu mengelola sumber daya manusia, sumber daya keuangan dan sumber daya teknik yang ada.

Di dalam melakukan suatu usaha yang berorientasi pada penciptaan keuntungan (profit oriented), maka perlu dianalisa berapa pendapatan yang akan diterima dan biaya-biaya yang akan dikeluarkan. Sumber utama pendapatan suatu kinik kesehatan berasal dari jumlah pasien yang berobat dimana semakin banyak pasien yang berobat maka semakin banyak pendapatan yang diperoleh [2]. Dengan banyaknya klinik kesehatan yang beroperasi maka pihak klinik perlu untuk 
menganalisa tarif yang akan ditetapkan sesuai dengan fasilitas-fasilitas yang ada sehingga bisa bersaing dengan klinik kesehatan yang lain dan pada akhirnya dapat memberikan keuntungan yang layak [3].

\section{Rumusan Masalah}

1. Bagaimanakan melakukan analisa Break Even Point pada Klinik Kesehatan Al Jadid Surabaya berdasarkan input tarif yang berlaku?

2. Bagaimanakan melakukan analisa Net Present Value pada Klinik Kesehatan Al Jadid Surabaya berdasarkan input tarif yang berlaku?

\section{Tujuan dan Manfaat Penelitian}

\section{Tujuan Penelitan}

Untuk menganalisa tarif yang berlaku pada saat ini sehingga dapat memberikan keuntungan yang layak sesuai dengan fasilitas-fasilitas yang diberikan sehingga dapat digunakan untuk

\section{Manfaat Penelitian} mengembangkan dan menunjang kehidupan klinik tersebut

1. Dapat meningkatkan kemampuan dalam hal penciptaan ide, perbaikan, pengembangan konsep dan metode pengembangan usaha

2. Dapat memberikan masukan dalam menentukan keuntungan yang layak dicapai

\section{TINJAUAN PUSTAKA}

\section{Biaya}

Pengertian Biaya, hubungan biaya dengan faktor - faktor dalam usaha dapat dibedakan menjadi beberapa bagian [4] :

a. Biaya menurut hubungan dengan produk. Biaya pabrik (biaya produksi) berupa biaya untuk : bahan langsung, buruh langsung dan biaya overhead langsung. Biaya komersial merupakan penjumlahan dari biaya pemasaran dan biaya administrasi [5].

b. Biaya menurut hubungannya dengan volume produksi. Biaya variabel adalah biaya yang besarnya berubah secara proporsional dengan perubahan volume atau jumlah unit produksi. Biaya tetap adalah biaya yang besarnya selalu tetap untuk periode tertentu dan tidak tergantung pada volume kegiatan atau jumlah unit produksi yang dihasilkan. Biaya tetap ini akan berkurang per unit produk bila volume poduksi meningkat. Biaya semi variabel adalah biaya yang mencakup suatu jumlah yang sebagian tetap dalam suatu output yang relevan dan sebagian lainnya bervariasi sebanding dengan perubahan input [2].

c. Biaya yang berhubungan dengan departemen fabrikasi

Biaya departemenn produksi adalah biaya yang digunakan untuk operasi secara manual atau mesin yang dilaksanakan langsung atas produk atau biayanya. Biaya departemen jasa adalah biaya yang dikeluarkan oleh departemen jasa untuk memberikan jasa-jasa yang bermanfaat bagi departemen lainnya [6]. Biaya bersama (common cost) adalah biaya yang berasal dari penggunaan fasilitas atau jasa-jasa oleh dua operasi atau lebih. Biaya gabungan (joint cost) adalah biaya yang terjadi jika terdapat produksi suatu jenis barang yang saling bergantungan.

d. Biaya yang berhubungan dengan satu periode akuntansi. Biaya untuk pengeluaran modal yaitu biaya yang dikeluarkan untuk maksud mendapatkan manfaat dalam periode masa depan dan dicatat sebagai harta. Biaya untuk pengeluaran modal yaitu biaya yang dikeluarkan untuk maksud mendapatkan manfaat dalam periode masa depan dan dicatat sebagai harga. Biaya untuk pengeluaran pendapatan yaitu biaya yang dikeluarkan untuk memberi manfaat pada masa sekarang [5][7].

\section{BEP dan Depresiasi}

Analisa Break Even Point (BEP) adalah titik keseimbangan antara total biaya dan total penjualan atau titik aktifitas (volume produksi) dan penjualan dimana tidak diperoleh keuntungan maupun kerugian karena total pendapatan sama dengan total pengeluaran. Analisa ini untuk menganalisa biaya-biaya dan volume penjualan serta jumlah keuntungan yang diperoleh [8] [9]. 


$$
\begin{aligned}
& \text { BEsales }=1-\frac{\text { Total Fixed Expences }}{(\text { volume in } \mathrm{Rp})} \\
& \frac{\text { Total Variable Expences }}{\text { Total Sales Value }(\mathrm{Rp})}
\end{aligned}
$$

BE sales $=$
$($ volume in unit $)$$\quad \begin{gathered}\text { Total Fixed Expences } \\ \text { Contribution Margin per Unit }\end{gathered}$

$$
\mathrm{BEP}=\frac{\text { Fixed Cost }}{\text { Price }- \text { Variable Cost }}
$$

$$
\begin{gathered}
\text { Sales Level }=\frac{\text { Fixed Cost }+ \text { Profit Desired }}{100 \%-\text { Variable Cost as \% Sales }} \ldots \\
\text { Contribution Margin }(\mathrm{CR})=\frac{(\text { Total Biaya - Total Variabel Cost })}{\text { Total Sales }}
\end{gathered}
$$

Analisa dengan BEP dibentuk dengan dasar asumsi dan batasan sebagai berikut [9] : (a) biayabiaya yang dibentuk dapat dikelompokkan atas biaya tetap (fixed cost) dan biaya berubah (variable const), (b) biaya tetap konstan pada periode waktu tertentu, (c) biaya berubah mempunyai hubungan linier terhadap hasil penjualan atau berubahnya unit yang diproduksi, (d) tingkat inflasi tetap.

Depresiasi dapat didefinisikan sebagai penurunan nilai dalam pasar atau market value dari fixed asset [2] [10]. Sedangkan definisi lan dari depresiasi adalah sebagai penurunan nilai dari fixed asset karena pemakaian dan pertambahan waktu [5][3]. Metode untuk menghitung besarnya depresiasi antara lain : (a) Straight Line; (b) Sum of YearDigits; (c) Declining Balance; (d) Sinking Fund. Pada penelitian ini digunakan metode straight line dengan rumus [1] [8]:

$$
\text { DT }=\frac{p-f}{n}
$$

$$
\begin{aligned}
& \mathrm{p}=\text { harga atau nilai dari aset saat sekarang } \\
& \mathrm{f}=\text { nilai sisa, yaitu nilai atau harga aset tersebut pada akhir pemakaian } \\
& \mathrm{n}=\text { umur atau lama pemakaian }
\end{aligned}
$$

Modal dalam klinik kesehatan ini dimaksudkan untuk menentukaan berapa ongkos yang secara riil ditanggung oleh perusahan dari suatu sumber dana. Sumber dana dapat bermacammacam bias dari pemerintah, perorangan, kelompok, lembaga keuangan atau pinjaman bank. Dalam penelitian ini besarnya pinjaman yang ditanggung oleh Klinik Al - Jadid adalah bantuan dari Yayasan Nur Fadila sebesar Rp 285.000.000,- dengan bunga (bagi hasil) 12\% per tahun dalam jangka waktu 5 tahun. Namun bangunan dan beberapa fasilitas klinik sudah disiapkan oleh yayasan. Pada perkembangan selanjutnya klinik Nur Fadila diberi wewenang sendiri dalam mengelola usahanya sehingga dapat mempercepat arus pengadaan atau pembayaran usaha klinik tersebut. 


\section{Cash Flow}

Cash Flow adalah aliran dana atau arus dana baik yang masuk maupun yang keluar dalam suatu periode tertentu dimana tujuan dari pengelolaan arus dana ini adalah sebagai berikut [6] : (1) menjamin tersedianya dana yang cukup pada saat dibutuhkan dan dana yang berlebih dapat digunakan secara efektif; (2) memberikan informasi yang akurat, tepat waktu dan tepat guna kepada manajemen untuk digunakan sebagai dasar dalam pengambilan keputusan mengenai pendanaan.

\section{Net Present Value (NPV)}

Metode NPV dapat dikategorikan sebaga metode discounting, dimana net cash flow tiap tahun, di masa yang akan datang discount dengan suatu tingkat bunga tertentu sebesar tingkat bunga dari investasi yang akan diperoleh dikurangi dengan investasi awal [7][10]. Kriteria keberhasilan suatu investasi dengan menggunakan metode NPV adalah : (1) proyek diterima bila NPV bertanda positif; (2) proyek tidak diterima bila NPV bertanda negatif.

$$
\begin{aligned}
& N P V=\sum_{t=1}^{n} \frac{R_{t}}{(1+K)^{t}}-C \\
& \mathrm{Rt}=\text { net cash flow saat } \mathrm{t} \\
& \mathrm{C}=\text { besarnya investasi awal } \\
& \mathrm{K}=\text { biaya modal } \\
& \mathrm{t}=\text { periode waktu }
\end{aligned}
$$

\section{METODE}

\section{Pencarian Data Time Series}

Data yang akan diolah merupakan data time series atau data berkala, karena merupakan data yang dikumpulkan dari tahun ke tahun. Data yang dikumpulkan dan diolah adalah dari tahun 2013 sampai tahun 2015. Selanjutnya data ini digunakan untuk : (a) menentukan tarif kelas paviliyun berdasarkan tarif yang berlaku saat ini; (b) analisis Break Even Point (BEP) berdasarkan data yang sudah ada; (c) analisa NPV sebesar 12\%; (d) analisa kinerja keuangan klinik Al-Jadid sehingga diperoleh keuntungan sesuai dengan yang drencanakan.

\section{Teknik Pemecahan Masalah}

a. Penentuan Bed Occupancy Rate. Dalam menganalisa tingkat pemakaian tempat tidur, perlu dianalisa beberapa variabel yang mempengaruhinya Antara lain : jumlah tempat tidur yang tersedia, jumlah pasien yang rawat inap, jumlah hari selama perawatan, jumlah pasien yang keluar

b. Menetapkan Tarif Kelas Paviliyun. Dengan mengetahui tarif yang ada maka BEP dapat diketahui. Adapun tarif yang berlaku untuk kelas I $=\mathrm{Rp} 125.000,-;$ kelas II $=\mathrm{Rp} 65.000,-;$ kelas III = Rp 45.000,-

c. Analisa BEP. Dikelompokkan elemen-elemen biaya tetap (fixed cost) yang meliputi gaji karyawan, penyusutan investasi (perlengkapan dan kelengkapan kamar), peyusutan gedung, biaya pemeliharaan dan biaya bunga pinjaman. Sedangkan biaya berubah (variabel cost) meliputi : biaya listrik, biaya telepon, biaya alat/bahan dokter, biaya alat/bahan ruangan, biaya obat, biaya air, biaya lain-lain.

d. Analisis Net Present Value. Setelah didapat tarif kelas yang berlaku maka dihitung nilai BEP. Selanjutnya dapat ditentukan keuntungan yang diperoleh dengan NPV sebesar $12 \%$ dari investasi yang telah ditanamkan.

e. Analisa Kinerja Keuangan. Dalam hal ini penerimaan yang diperoleh harus lebih besar dari pengeluaran sehingga klinik dapat mencapai keuntungan seperti yang diharapkan. 


\section{HASIL DAN PEMBAHASAN}

\section{Data Jumlah Pasien}

Jumlah pasien rawat inap (JP) di tahun 2014 adalah 612 orang dengan rata-rata rawat inap (L) $=1,2$ hari. Sehingga banyaknya hari perawatan $(\mathrm{JHP})=\mathrm{JP} \times \mathrm{L}=734,4$ hari. Klinik Al-Jadid untuk kelas I memiiki 4 tempat tidur, kelas II dengan 8 tempat tidur dan kelas III dengan 12 tempat tidur.

\section{Data Investasi Umum}

Tabel 1. Data Investasi Umum

\begin{tabular}{|c|l|r|}
\hline No. & \multicolumn{1}{|c|}{ Jenis Investasi } & Nilai \\
\hline 1. & Tanah & 150.000 .000 \\
\hline 2. & Bangunan & 850.000 .000 \\
\hline 3. & $\begin{array}{l}\text { Perlengkapan Kamar } \\
\text { meja, kursi, bantal, } \\
\text { guling, dsb) }\end{array}$ & 52.000 .000 \\
\hline 4. & Lemari Es & 20.200 .000 \\
\hline 5. & Lemari Alumunium & 34.800 .000 \\
\hline 6. & Televisi Berwarna & 42.600 .000 \\
\hline 7. & $\begin{array}{l}\text { Pendingin Ruangan } \\
\text { (AC) }\end{array}$ & 32.400 .000 \\
\hline 8. & Jam Elektronik & 2.600 .000 \\
\hline 9. & $\begin{array}{l}\text { Banjik (Bangku Injak } \\
\text { Kayu) }\end{array}$ \\
\hline 10. & Rak TV & 960.000 \\
\hline 11. & Meja Makan & 2.300 .000 \\
\hline 12. & Rak Handuk & 880.000 \\
\hline 13. & Wastafel & 12.800 .000 \\
\hline 14. & Closet Duduk & 4.600 .000 \\
\hline \multicolumn{2}{|c|}{ Total } & 1.211 .161 .840 \\
\hline
\end{tabular}

Tabel 2. Data Investasi Perlengkapan

\begin{tabular}{|c|l|r|}
\hline No. & \multicolumn{1}{|c|}{ Jenis Investasi } & Nilai \\
\hline 1. & Perlengkapan Kantor & 6.600 .000 \\
\hline 2. & $\begin{array}{l}\text { Perlengkapan Kepala } \\
\text { Ruangan }\end{array}$ & 9.540 .000 \\
\hline 3. & Perlengkapan Ruang Rapat & 5.225 .000 \\
\hline 4. & $\begin{array}{l}\text { Perlengkapan Ruang } \\
\text { Verifikasi Akuntan }\end{array}$ & 7.350 .000 \\
\hline 5. & $\begin{array}{l}\text { Perlengkapan Loket } \\
\text { Pembayaran }\end{array}$ & 8.960 .000 \\
\hline 6. & $\begin{array}{l}\text { Perlengkapan Ruang } \\
\text { Perpustakaan }\end{array}$ & 5.120 .000 \\
\hline 7. & Perlengkapan Ruang Tunggu & 3.900 .000 \\
\hline 8. & Perlengkapan Dapur & 9.110 .000 \\
\hline 9. & Perlengkapan Kamar Ganti & 3.200 .000 \\
\hline 10. & Perlengkapan Kamar Perawat & 9.300 .000 \\
\hline 11. & Perlengkapan Lain-lain & 3.200 .000 \\
\hline \multicolumn{2}{|c|}{ Total } & 71.505 .000 \\
\hline
\end{tabular}

\section{Data Biaya Tetap}

a. Gaji Karyawan. Total pengeluaran untuk gaji karyawan klinik adalah sebesar Rp 38.550.000,/bulan atau sebesar Rp 462.600.000,-/tahun.

b. Depresiasi. Dengan menggunakan metode straight line diperoleh hasil untuk bangunan nilai saat ini Rp 1.850.000.000,- dengan asumsi umur 20 tahun dan nilai sisa $=0$ sehingga deresiasinya $=92.500 .000$ /tahun Sedangkan depresiasi pelengkapan dan kelengkapan dengan nilai sekarang $=475.585 .000$, umur asumsi 5 tahun dengan nilai sisa $=0$, maka depresiasinya $\mathrm{Rp}$ 95.117.000/tahun. Sehingga total depresiasi untuk bangunan dan perlengkapan klinik sebesar Rp 187.617.000,-

c. Biaya Pemeliharaan. Dalam hal ini yang dimaksud dengan biaya pemeliharaan adalah biaya beban yang dipergunakan oleh klinik secara menyeluruh meliputi pemeliharaan gedung, alatalat medis, alat-alaat teknik dan kantor sehingga mencapai Rp 10.000.000,-

d. Bunga Pijaman

Tabel 3. Rencana Pengembalian Pinjaman dan Pembayaran Bunga

\begin{tabular}{|c|c|c|c|c|}
\hline $\begin{array}{c}\text { Akhir } \\
(\mathrm{Th})\end{array}$ & $\begin{array}{c}\text { Bunga yang } \\
\text { harus dibayar }\end{array}$ & $\begin{array}{c}\text { Angsuran } \\
(\mathrm{Rp})\end{array}$ & $\begin{array}{c}\text { Total } \\
\text { Pembayaran }\end{array}$ & $\begin{array}{c}\text { Sisa Pinjaman } \\
(\mathrm{Rp})\end{array}$ \\
\hline 0 & - & - & - & 285.000 .000 \\
\hline 1 & 34.200 .000 & 57.000 .000 & 91.200 .000 & 228.000 .000 \\
\hline 2 & 27.360 .000 & 57.000 .000 & 84.300 .000 & 171.000 .000 \\
\hline 3 & 20.520 .000 & 57.000 .000 & 77.520 .000 & 114.000 .000 \\
\hline 4 & 11.400 .000 & 57.000 .000 & 68.400 .000 & 57.000 .000 \\
\hline 5 & 6.840 .000 & 57.000 .000 & 63.840 .000 & - \\
\hline
\end{tabular}


Total Biaya Tetap $=$ Gaji karyawan $(460.260 .000)+$ Depresiasi $(187.617 .000+$ Pemeliharaan $(10.000 .000)+$ Bunga Pinjaman $(34.200 .000)=692.077 .000$

Tabel 4. Total Biaya Berubah (Variable Cost)

\begin{tabular}{|c|l|c|}
\hline No. & \multicolumn{1}{|c|}{ Item Biaya } & \multicolumn{1}{c|}{ Nilai } \\
\hline 1. & $\begin{array}{l}\text { Biaya alat atau } \\
\text { bahan dokter }\end{array}$ & $4 \%$ dari penerimaan \\
\hline 2. & $\begin{array}{l}\text { Biaya alat atau } \\
\text { bahan ruangan }\end{array}$ & $2,3 \%$ dari penerimaan \\
\hline 3. & Biaya obat-obatan & $3 \%$ dari penerimaan \\
\hline 4. & Biaya Listrik & $1,5 \%$ dari penerimaan \\
\hline 5. & Biaya Air & $1,3 \%$ dari penerimaan \\
\hline 6. & Biaya Telepon & $1 \%$ dari penerimaan \\
\hline 7. & $\begin{array}{l}\text { Baya Pajak } \\
\text { Penghasilan }\end{array}$ & $10 \%$ dari penerimaan \\
\hline 8. & Biaya Lain-lain & $2,5 \%$ dari penerimaan \\
\hline
\end{tabular}

Jumlah tempat tidur yang tersedia di Klinik Kesehatan Al-Jadid dapat dihitung sebagai berikut: JTS $=365 \times$ JTT $=365 \times 48=17.520$ tempat tidur. Hal ini berarti pemakaian maksimal tempat tidur selama setahun sebesar 17.520, tetapi karena pemakaian tempat tidur Klinik hanya $49 \%$ maka jumlah tempat tidur yang ditempati selama satu tahun adalah 8585 tempat tidur.

$\mathrm{BEP}=\frac{\mathrm{FC}}{\mathrm{P}-\mathrm{Vc}}=\frac{692.077 .000}{45.000(49 \%)-(25,6 \%)(56.711)}=\operatorname{Rp} 92.928,-$

Tarif kelas yang dipeoleh pada BEP merupakan tarif kelas dimana tidak diperoleh keuntungan atau kerugian. Untuk menganalisa berapa tarif kelas yang layak, maka ditentukan tarif kelas minimum. Dari cara coba-coba (trial and error) untuk memperoleh tarif kelas pada tingkat bunga modalnya dengan cara menaikkan tarif kelas pada BEP sebesar X\%, sehingga dapat memberikan hasil yang layak menurut metode NPV pada tingkat biaya modal sebesar $12 \%$.

Tabel 5 Tarif Kelas Pada $\mathrm{x}=250 \%$ Rp 92.928

\begin{tabular}{|c|c|c|c|c|c|c|c|c|}
\hline No & Pendapatan & $\begin{array}{c}\text { Variabel } \\
\text { Cost }\end{array}$ & Fixed Cost & $\begin{array}{c}\text { Sisa Hasil } \\
\text { Pendapatan }\end{array}$ & Depresiasi & $\begin{array}{c}\text { Sisa Hasil } \\
\text { Pendapatan } \\
\text { Setelah Pajak }\end{array}$ & $\begin{array}{c}\mathrm{p} / \mathrm{f} \\
12 \%\end{array}$ & NPV \\
\hline & - & - & - & - & - & - & - & -2.475 .585 .000 \\
\hline 1. & 1.242 .033 .804 & 317.960 .654 & 278.077 .000 & 645.996 .150 & 187.617 .000 & 458.379 .150 & 0,8929 & 409.286 .743 \\
\hline 2. & 1.242 .033 .804 & 317.960 .654 & 271.237 .000 & 652.836 .150 & 187.617 .000 & 465.219 .150 & 0,7972 & 370.872 .707 \\
\hline 3. & 1.242 .033 .804 & 317.960 .654 & 264.397 .000 & 659.678 .150 & 187.617 .000 & 472.059 .150 & 0,7118 & 336.011 .703 \\
\hline 4. & 1.242 .033 .804 & 317.960 .654 & 257.557 .000 & 666.516 .150 & 187.617 .000 & 478.899 .150 & 0,6355 & 304.340 .410 \\
\hline 5. & 1.242 .033 .804 & 317.960 .654 & 250.717 .000 & 673.356 .150 & 187.617 .000 & 485.739 .150 & 0,5674 & 275.608 .394 \\
\hline 6. & $\begin{array}{l}\text { Sisa Nilai } \\
\text { Bangunan }\end{array}$ & & & 1.573 .500 .000 & & 138.875 .000 & & 785.139 .750 \\
\hline & & & & & & & Total & 5.674 .707 \\
\hline
\end{tabular}

\section{Analisa Kinerja Keuangan}

Klinik Al-Jadid memiliki 3 kelas yaitu : (1) Kelas I terdiri dari 8 kamar dengan 8 tempat tidur (1 kamar 1 pasien); (2) Kelas II terdiri dari 8 kamar dengan 16 kamar tidur (1 kamar 2 pasien); (3) Kelas III terdiri dari 8 kamar dengan 24 tempat tidur (1 kamar 3 pasien). Adapun tarif yang sedang berlaku saat ini adalah : (a) Kelas I : Rp 125000,-; (b) Kelas II : Rp 65.000,-; (c) Kelas III : Rp 45.000,-. Dengan mengetahui biaya tetap dan biaya berubah serta tariff yang berlaku maka BEP diketahui sebesar Rp 36.919,-- kemudian dengan cara coba - coba (trial and error) pada suatu cash flow dengan metode NPV lebih besar dari nol maka besarnya Rp 92.928. Tarif NPV tersebut melebihi dari tarif Kelas III (tarif terendah) yang disebabkan adanya biaya pengembalian modal dengan jangka waktu 5 tahun. 
Khusus klinik Kelas I memberikan subsidi silang untuk kelas III. Jumlah subsidi yang dikeluarkan sebesar Rp 10.000, denan rincian sebagai berikut : Tarif BEP $=\mathrm{Rp} 36.919,-+$ subsidi $=\operatorname{Rp} 36.919,-+\operatorname{Rp~10.000,-}=\operatorname{Rp~46.919,-.~Dari~tariff~BEP~di~atas~hampir~sama~dengan~tariff~}$ kelas III yang berlaku yaitu sebesar Rp 45.000,-

\section{KESIMPULAN}

\section{Kesimpulan}

1. Dengan tingkat pemakaian tempat tidur $49 \%$, maka jumlah tempat tidur yang terpakai selama setahun adalah 8585 tempat tidur

2. Tarif kelas pada BEP yaitu dengan memasukkan tarif yang berlaku, fix cost dan variable cost adalah sebesar Rp 36.919

3. Tarif kelas yang ditentukan dengan metode NPV dengan tingkat bunga $12 \%$ adalah sebesar Rp 92.298

\section{Saran}

1. Faktor yang cukup penting dalam meningkatkan tingkat pemakaian tempat tidur adalah pelayanan yang baik dari pihak Kinik Kesehatan Al-Jadid. Hal ini perlu diperhatikan agar dapat bersaing dengan klinik kesehatan yang ada

2. Sebaiknya klinik kesehatan Al-Jadid dapat bekerjasama (mengadakan rujukan) dengan perusahaan-perusahaan sehingga dapat meningkatkan tingkat penggunaan tempat tidur

3. Dengan tingkat pemakaian tempat tidur di Klinik sebesar $49 \%$ berarti pihak klinik tidak perlu menambah jumlah tempat tidur atau melakukan pengembangan klnik kesehatan, dimana hal ini menunjukkan kurangnya pemanfaatan fasilitas perawatan klinik oleh masyarakat

\section{Daftar Pustaka}

[1] Gavlakova, P., Kliestik, T. 2014. Credit Risk Models and Valuation. In: Conference: 4th International Conference on Applied Social Science (ICASS). Advances in Education Research, Singapore. Vol.51, pp. 139-143. ISSN: 2160-1070

[2] Direktorat Jenderal Pariwisata. 2007. Pariwisata Tanah Air Indonesia. Direktorat Jenderal Pariwisata. Jakarta

[3] Ziobrowski, A. 2007. Resort Timeshares as an Investment. Appraisal Journal, October 2007, 371-380

[4] Eugene 1. Grant, W. Grant Ireson, Richards Leaven Worth. 2013. Ekonomi Teknik. Cetakan 7. Jilid 1. Prentice Hill. London

[5] Hovey, M. 2002. Is Timeshare Ownership and Investment Product? Journal of Financial Services Marketing, 7, 141-150

[6] Larson, S. \& Larson, R. 2009. Purchase a Time-Share Interval or Rent Hotel Rooms Preparing for a Discussion with Clients. Journal of Financial Planning, 22, 44-52

[7] Powanga, A. 2008. An Economic Analysis of a Timeshare Ownership. Journal of Retail \& Leisure Property, 7, 69-83

[8] Lorincova, S., Balazova, Z. 2016. Innovative solutions in selected logistics companies in Slovakia. Scientific Journal on Transport and Logistics. Vol. 5, No. 2, pp. 28-41. ISSN 1804-3216

[9] Larson, S. \& Larson, R. 2009. Purchase a Time-Share Interval or Rent Hotel Rooms Preparing for a Discussion with Clients. Journal of Financial Planning, 22, 44-52

[10] Soehardi Sigit, 2010. Analisa Break Even Point. Edisi Ketiga. BPFE. Yogyakarta

[11] Suprapto, Adikoesoemo. 1997. Manajemen Rumah Sakit. Cetakan Ketiga. Penerbit Pustaka. Sinar Harapan. Semarang

[12] Swastha Bashu. 2007. Manajemen Pemasaran I. Cetakan Ketiga. Penerbit Karunika. Universitas Negeri Jakarta 
- Halaman ini sengaja dikosongkan - 